\title{
Words in a Cultural Context
}

\author{
Kathryn Kavanagh, Executive Director, Dictionary Unit for South African \\ English, Rhodes University, Grahamstown, Republic of South Africa
}

\begin{abstract}
Successful communication is dependent upon an adequate level of cultural as well as linguistic understanding. Language is itself part of culture and reflects social structures and attitudes. This paper examines the case for dictionaries to carry cultural as well as lexical information. It reviews the American tradition and purpose of including cultural material in dictionaries, and considers the nature and scope of cultural information contained in a number of modern American and European dictionaries. Various means of presenting cultural information are also examined. The paper concludes by considering the implications for lexicographers developing dictionaries in multicultural South Africa.
\end{abstract}

Keywords: COMMUNICATION, CROSS-CULTURAL COMMUNICATION, CULTURAL INFORMATION, CULTURE, CURRICULUM, DICTIONARIES FOR SPECIAL PURPOSES, DICTIONARY, DICTIONARY DESIGN, ENCYCLOPEDIA, ENCYCLOPEDIC DICTIONARIES, LANGUAGE, LEXICOGRAPHY, MULTICULTURAL SOCIETY, SOUTH AFRICA

Opsomming: Woorde binne 'n kulturele konteks. Suksesvolle kommunikasie berus op 'n voldoende vlak van kulturele sowel as taalkundige begrip. Taal self is deel van kultuur en weerspieël sosiale strukture en houdings. Hierdie artikel ondersoek die insluiting van sowel kulturele as leksikale inligting in woordeboeke. Dit beoordeel die Amerikaanse tradisie en doel daarmee om kulturele materiaal in woordeboeke in te sluit, en oorweeg die aard en omvang van kulturele inligting vervat in 'n aantal moderne Amerikaanse en Europese woordeboeke. Verskillende maniere om kulturele inligting aan te bied, word ook ondersoek. Die artikel sluit af deur die implikasies vir leksikograwe te oorweeg wat woordeboeke saamstel in multikulturele Suid-Afrika.

Sleutelwoorde: KOMMUNIKASIE, INTERKULTURELE KOMMUNIKASIE, KULTURELE INLIGTING, KULTUUR, KURRIKULUM, WOORDEBOEKE MET SPESIALE OOGMERKE, WOORDEBOEK, WOORDEBOEKONTWERP, ENSIKLOPEDIE, ENSIKLOPEDIESE WOORDEBOEKE, TAAL, LEKSIKOGRAFIE, MULTIKULTURELE SAMELEWING, SUID-AFRIKA

\section{Cultural factors and successful communication}

My approach in this paper is not that of an academic who has spent several years researching language and its cultural context, but as a practising lexicographer who has been forced to consider the benefits and the problems of

* This paper was presented as a keynote address at the Fifth International Conference of the African Association for Lexicography, held at the University of Stellenbosch, Stellenbosch, 35 July 2000.

Lexikos 10 (AFRILEX-reeks/series 10: 2000): 99-118 
including cultural information in dictionaries. As lexicographers, we need to examine and reassess from time to time what is needed or expected by the users of our products, so I am going to consider the content of dictionaries, not so much the headword list but rather the cultural content, to see whether it meets the needs, and potential needs, of dictionary users.

We communicate mainly with words, and in order to communicate successfully with others we need to know the generally accepted meanings of words in our language, and to be able to structure them coherently in a phrase or sentence. If people are to interpret us correctly, we need a shared understanding of meaning and a shared knowledge of some basic grammatical rules.

We also have to take into account other factors. We need, for instance, to have some idea of register and tone of voice: to know when to use formal or informal language, or slang, in appropriate contexts, and to be able to appreciate the language level and tone of others. We learn much of this in relation to our own language as we grow up. In dictionaries, some social information can be coded in "register labels" at entries for individual words. However, standard dictionary entries give little further information about good manners and social norms.

Linguistic interaction is regularly constrained by cultural factors, such as age, seniority, or gender. We need to be aware of social conventions: when to speak, how to talk to people older than us, how to be polite. In our own language and in our own cultural setting this comes naturally. In other settings we may feel insecure. But we do need to know what is considered rude by people of other cultures, so that we can avoid it. For instance, we need to know how directly we can ask for something. Is it all right to be direct, or should you get round to the subject slowly? Is it all right to say "I want some chocolate", or should you say "Please may I have some chocolate?". Most British people would agree that introducing a request with "Please may I have ...", rather than saying "I want ..." or "Give me ...", shows better manners, and is more likely to prompt a favourable response. In other languages, amongst other groups of people, it is perfectly acceptable to express a want directly. We also need to know whether it is polite ever to say "no"? And what happens if you do something wrong, or inconvenience someone? In some cultures it is polite both to apologise and to give an excuse. Multilingual societies, such as ours, present a broad range of behaviour patterns, several different frameworks of acceptability.

We need also to consider how people of different cultures talk about sensitive topics, such as death or sexual relationships. Indeed, is it appropriate to talk about such topics at all? British people, and probably many others, especially those who are creeping past midlife, may avoid talking about death, or, if they need to talk about someone who has died recently, may speak more softly and use expressions like pass on or pass away rather than use the bleak and callous-sounding die. They use a euphemism. This may be to show respect for the dead, but is sometimes also due to a superstition that talking about death may 
hasten your own. There is a feeling that it may bring bad luck, that it may be "tempting fate". In such situations there needs to be cultural as well as lexical sensitivity. And what about the funeral arrangements? The type of occasion, and whether you are invited to a wake or perhaps an after-tears party, can say much about attitudes to death and people's ease with the subject.

In the case of relationships, some cultural groups may talk frankly about very personal matters, others may not feel it appropriate to discuss relationships at all. A misguided question may be considered extremely rude and put up barriers to further communication. We need to know about words and their meanings, but we also need to know about attitudes, manners, and social norms.

Choice of words, ways of approaching certain subjects, knowing which subjects to avoid with whom, and the level of detail appropriate to a situation are difficult for outsiders to know yet vital to communication at all but the most basic level. Correctness and intelligibility may rest on purely linguistic factors, but successful communication depends on an adequate knowledge of language and an understanding of what it is appropriate to say in particular situations. Gumperz (1970: 205) comments: "Whereas linguistic competence covers the speaker's ability to produce grammatically correct sentences, communicative competence describes his ability to select, from the totality of grammatically correct expressions available to him, forms which appropriately reflect the social norms governing behaviour in specific encounters."

Communication requires a degree of lexical and syntactic competence, and cultural competence. We cannot operate in a cultural vacuum. In South Africa, a country where people are being positively encouraged to learn another language and to communicate across cultures, the need to develop cultural as well as linguistic awareness should be emphasised. Successful communication involves background knowledge, shared information about context, traditions, and attitudes, shared images in the mind's eye. Problems of cross-cultural communication are not necessarily a misunderstanding of words, but a lack of understanding of the concepts behind words. A major source of information for many language learners is a bilingual dictionary. Authors and editors of bilingual dictionaries know just how difficult it is to find "semantic equivalents" even for languages of similar cultures. There is often a need to offer the user a "communicative equivalent", which takes into account cultural factors. Both Gouws (1996) and Kotzé (1999) have addressed these issues in volumes of Lexikos. I would suggest that many a dictionary user would like to know more about the cultural differences which cause such problems and the reasons for the selection of a particular communicative equivalent.

Successful communication would seem to involve more than a knowledge of semantics and syntax. As lexicographers, we need to consider the implications for dictionary compilation. Dictionaries clearly have a responsibility for imparting or enhancing knowledge of a language. They provide lists of words with definitions and other very specific categories of information. Generally, 
they do not provide explanations of cultural behaviour. In the past year, in lexicographic seminars arranged by the Pan South African Language Board, there has been much emphasis on the macrostructure and microstructure of dictionaries. So far, there has been little or no discussion of any cultural dimension. The relationship between language and culture is widely recognised, and I believe now is the time in South Africa to review that relationship vis-à-vis dictionaries.

\section{Culture and language}

Let us have a closer look at what we mean by "culture", and especially the relationship of culture with language. What is culture? Culture is a word with various different senses. In one sense it may include the arts - the theatre, literature, music, and painting - which are the products of human intellectual achievement. In another sense it may refer to the whole gamut of traditional beliefs and practices, activities and way of life, of a particular group of people.

In connection with the first sense, which may be described as "achievement culture", or "culture with a capital C", we can think of famous South Africans like J.M. Coetzee, Zanemvula Mda, Miriam Makeba, Hugh Masekela, and many more. As a result of their achievements they have become part of a national South African culture and are becoming more widely known. We can think also of internationally famous people and works of art - Beethoven and his symphonies, Van Gogh and his paintings, Shakespeare and his poetry and plays. These people and their achievements are no longer associated only with an ethnic or national culture but have taken their place on the international stage. They are part of "high culture", which may sometimes be referred to as "civilisation". Civilisation originally embraced the development of society and the arts in Europe, but it has since absorbed cultural achievement from the rest of the world. In a paper presented to the English Academy, Laurence Wright (2000, in press) said of civilisation that it "comes into being through gathering together and comparing the character and results, the achievements of different cultures. It is inherently transcultural, to some extent metacultural".

A more challenging approach is to focus on the behavioural or social aspects of culture, the second sense of culture that I mentioned. This is sometimes referred to as "behavioural culture" or "little c" culture. The anthropologist Walter Goodenough (1957), quoted in Wardhaugh (1986: 211), concentrates on this aspect of culture, saying: "The culture of a society consists of the particular knowledge and beliefs that members of a community have which enable them to operate in a manner acceptable to the group, and in any role that the group finds acceptable". Gabriele Becher (1995: 294), quoted by Kotzé (1999), says on the meaning of culture that it is "the sum total of a social community's behaviour patterns, including the 'rules' of behaviour and its (material and immaterial) results". Becher also relates language to culture, saying that "lan- 
guage is considered to be a cultural product, and at the same time, language may be considered part of the manifestation of culture-specific behaviour".

This sense of culture is more about ordinary people and their daily life, how they live, the places they go to, the institutions they have contact with, their social interactions, their attitudes towards the issues and situations that confront them, their beliefs and perceptions, and their priorities, i.e. "what makes them tick". "Little c" culture also includes aspects of life such as religious practices, education and employment, leisure activities, and sport. It is about people and their behaviour and values, and may be specific to a particular group of people or nationality. Knowledge of this type of culture is more relevant to language users in terms of communication, but it is also more difficult to pin down. It is more likely to be changing and developing, and has a range of manifestations dependent on age, gender, class, and education.

Language is important as a means of ethnic or cultural identity. An important function of a language is to enable speakers of that language to identify with a group or to separate themselves from it. We need to be aware that we all have "cultural baggage", ideas and patterns of behaviour that were absorbed or instilled into us as children, and we bring this consciously or unconsciously into our dealings and conversations with others. We need also to be aware that other people are doing the same.

The knowledge, beliefs, and practices of a particular society are reflected in its language. The vocabulary of a language can provide some evidence of what is considered culturally important, and there may be several words for the most familiar items and concepts. The American linguists Edward Sapir and Benjamin Lee Whorf (discussed in Kaschula and Anthonissen 1995, and Wardhaugh 1986) suggested that people's views of the world are conditioned largely by their mother tongue. Though the extent to which language itself determines and restricts the way in which speakers understand the world is in doubt, it seems clear that attitudes and language are closely interlinked. Social change produces linguistic change: new inventions and ideas bring new vocabulary, and in multicultural societies greater contact brings code-switching and code-mixing, borrowing, and assimilation.

Modern language-learning strategies promote familiarisation with the culture of users of the language. Course books include cultural information of all kinds, social, artistic, and institutional. English language course books, such as the Headway and Hotline series from Oxford University Press, and Patricia Pinnock's Xhosa course book, Xhosa: A Cultural Grammar for Beginners, help the learner become more aware of differences in lifestyle, heritage, and values. Such cultural frames of reference are especially important when the speaker's first language and the language being learned are linguistically and physically remote. In multicultural societies such as South Africa people have more opportunity to become sensitive to others' social practices through firsthand experience. 
Linguistic and cultural items are often one and the same and cannot be easily differentiated. People from different cultures have varied mental images of apparently simple items like house, taxi, even jelly. What about more complex terms at the centre of human life, like family, marriage, funeral, manners, and government? We all know these words, but we may have different images in our minds, different ideas of their meaning. For each of us the connotations are different. Take the word marriage, for instance. Does the term for you mean only one wife, or is it perfectly normal and acceptable to have several wives concurrently? Should you have one wife till death do you part, or is divorce possible? If so, can you remarry? Does marriage imply a religious service, or is it a civil contract? What is a common law wife? a customary marriage? And what about associated behaviour patterns? For instance, do the partners in a marriage choose each other, or do their parents choose for them? What is the relative status of each of the partners? What are their expected codes of behaviour are they expected to be faithful to each other? Is romance involved? Is marriage seen rather as an alliance between families? Does any payment, money or goods, change hands? Many more questions can be asked, but it seems to me that a cultural framework is necessary in order to interpret the meaning of a term like marriage satisfactorily.

Chaffey (1992) talks about the "degree of cultural loading" to refer to the amount of culture-specific knowledge a language user must have in order to be able to understand the full meaning of a lexical item. Social terms, like marriage, have a high degree of cultural loading.

Names also carry cultural information and have particular connotations. I am not thinking just of people's names but also the names of products, shops, companies, and institutions. They play an important part in the understanding of an expression but are rarely found in dictionaries. To understand simple sentences like "The bus dropped us at Sainsbury's" and "You can get them at Boots", you need to understand that these are names of shops, the former a supermarket, the latter a pharmacy chain. You could substitute "Spar" and "Clicks" in South Africa. Names of people and organisations also carry important connotations. If you hear a "household name", like Margaret Thatcher, Nelson Mandela, Wall Street, Microsoft, or de Beers, you do not just know that these are names of people, places, companies, and such like, but you also know something about them, their reputation, the cultural connotations behind the names. David Crystal (1997) says that "a cultural perspective is necessary ... to grasp the social significance of a linguistic feature ... or to follow the subject matter of daily conversation". Knowing the cultural connotations of a word, knowing the names of famous people and what they stand for, knowing about major events in a people's history, knowing its institutions, and even knowing the names of shops or brand names, are major factors in understanding a newspaper report or television programme, or just taking part in a casual conversation.

In South Africa we have eleven official languages. The claim of each language to equal status has little to do with linguistic merit, but is almost entirely 
about cultural and social factors: equitable treatment of people from different cultures and linguistic backgrounds, respect for human rights, respect for language rights, a desire to preserve long-standing cultural and social traditions, and more. Language is inextricably bound to culture, but yet we often separate them and try to avoid including cultural information in dictionaries on the grounds that it is extraneous or, more pragmatically, that the space can be more than taken up by lexical information. It is impossible to include everything, but we can try to give a fuller cultural picture in many instances.

\section{Dictionary or encyclopedia?}

It may be thought that cultural information should be presented in an encyclopedia rather than a dictionary. What is a dictionary, what is an encyclopedia? The difference may appear to be obvious. Think of a dictionary such as the Concise Oxford Dictionary, which has entries for words such as heritage, win, and although, or a bilingual English-Afrikaans dictionary, which has information about the same words in two languages. Then consider an encyclopedia like the Encyclopaedia Britannica: titles of articles in this work include fungi, brewing, funerary rites and practices, Tombouctou, and Mao Tse-Tung.

Traditionally, dictionaries are supposed to deal with the question "What does $x$ mean?", whereas an encyclopedia deals with the question "What is $x$ ?" or "Who is $x$ ?" or "Where is $x$ ?" An encyclopedia contains encyclopedic information, information about world-famous people, places, and institutions; politics and politicians; characters in literature, the theatre, and cinema; societies and social practices; the universe and natural phenomena. An entry for weather in a dictionary will give very different information from that contained in an encylopedia. It has been neatly said that encyclopedias give information about the world, rather than about the word. Information in encyclopedias is presented in articles which may be a few lines or a few pages long. They may be arranged alphabetically or thematically. Compare this with the brief, sometimes overconcise information about the words of a language that is presented in a dictionary.

The dictionaries we, as lexicographers, spend much of our time discussing present the bones of a language. They are general lexical dictionaries and give what are sometimes referred to as "dictionary definitions". The presence of purely linguistic information usually signals a dictionary rather than an encyclopedia. We talk often about distinct dictionary "types", but the concept of a dictionary may become quite fluid. In many dictionaries, definitions include an element of description over and above what is necessary to isolate the concept. The information may typically describe the function or use of the item concerned. Common examples are definitions for sugar or salt which describe the use of the substances. These are known as "encyclopedic definitions". Laurence Urdang (2000) reflects on the difference between the two types of definitions in his review of Hartmann and James's Dictionary of Lexicography. Incidentally, he 
also comments that "attempts at divorcing language from life and treating it as some sort of algebraic formula that was found somewhere engraved on a stone may be regarded by some as logically rigorous, but it is not only inelegant but useless". Dictionaries are often regarded as "containers of knowledge", and dictionary users may be less worried about discriminating between lexical and practical information than lexicographers. As Béjoint (1994: 18) says: "A dictionary is primarily an instrument to be used when one needs a piece of information about a word in particular, about the language in general, or about the world."

Let us look briefly at the dictionaries called "encyclopedic dictionaries" and the sort of information they provide. They are alphabetically arranged and contain linguistic information and encyclopedic or cultural information in the same volume. We might expect them to include more than simply lexical information about "little c" cultural terms such as family, manners, drinking, or birthdays, but in fact they rarely include this type of information. Nor do they include entries for locally famous people, places, events, etc. Whatever the language they are catering for, they are more likely to include information about Japan or Paris, Johann Sebastian Bach, or George Washington. This kind of information is part of general world knowledge, world culture, or civilisation. I would like to suggest that dictionaries need to contain more locally based items, and some elements at least of "little c" culture.

\section{The tradition of including cultural material in dictionaries}

The tradition, especially in the US, of including cultural, or encyclopedic, material in dictionaries can now be considered.

In Britain, the inclusion of encyclopedic information in dictionaries was denounced by Dean Richard Trench in 1857, in papers entitled "On some Deficiencies in our English Dictionaries". His grounds for rejecting such information were that it was irrelevant and it cluttered up the dictionary. This was just prior to the start of the New English Dictionary project, what was later to become the Oxford English Dictionary, and Trench had a profound influence on modern dictionary-making. Encyclopedic information was common in earlier dictionaries, including Samuel Johnson's of 1755, and is still a standard feature of many American dictionaries.

English dictionaries of the 16th and 17th centuries contained information on mythology, the theatre, religious sects, folkloric properties of flowers, and names and descriptions of cities and countries. During the 17th and 18th centuries the authority of the lexicographer increased. Mengham (1993: 112) says: "The lexicographer would determine what should be included in, and what should be excluded from, a body of knowledge that the pragmatic user of his work would learn to regard as the foundation of national language and culture." Johnson and later Noah Webster in the US held positions of power from which they could develop their own moral and political agenda in their dic- 
tionaries. Mengham considered that, in Johnson's case, he used his position as a means of "reinforcing the political status quo, religious authority, and cultural authoritarianism ...". A salutary reminder to beware of the dangers of bias in the selection and presentation of encyclopedic information.

In the US there has been a long-standing tradition of lexicographical prescriptivism. In the 18th and early 19th century there were unsuccessful attempts to set up an academy to legislate on linguistic standards. However, the success of Noah Webster's American Spelling Book (1783) and A Compendious Dictionary of the English Language (1806), and later works of Webster and Joseph Worcester, went some way towards satisfying desires to establish linguistic as well as political independence from Britain. In particular, Webster's American Dictionary of the English Language (1828) is a byword for patriotism and nationalism.

Since then, the objectives of American lexicography have been not so much to preserve the language but to indicate good usage and pronunciation. This was especially important following the immigration of people from many countries to the US in search of a better life. Dictionaries were, and still are, tools for education and self-improvement. They were seen as a means of educating foreigners about American ways, American culture, and American English, and regularly included encyclopedic as well as lexical and syntactic information. Dictionaries were also seen as a sign of social and cultural attainment and had an important place, second only to a Bible, in most homes. These dictionaries were compiled for the ordinary person, not the scholar. They were allpurpose reference books, the primary and often the only source of information. They contained scientific, technical, geographical, and biographical information, distributed through the main alphabetical list and in appendices. Webster's New International Dictionary (1909), named after Webster, not edited by him, contained sections on place names, quotations, vocabulary tests, proof-readers' marks, and more. A later edition, Webster's Third New International (1961), was criticised strongly for departing from this tradition and for becoming descriptive rather than prescriptive. It had no proper names apart from attributive uses, fewer illustrations, and no encyclopedic supplement. The expectations of the public were seriously disappointed.

Today, "the dictionary" is still important in the US. American dictionaries are intended to be user-friendly and satisfy the needs of the average person. They are also highly commercial products and many publishers outside the US have taken note of this. Some modern British dictionaries have followed the American line, notably the Collins Concise Dictionary, and the Oxford English Reference Dictionary.

\section{Cultural information in modern dictionaries}

Assuming the desirability of including encyclopedic or cultural information in dictionaries, we all know that printed dictionaries have space constraints, that 
every word has to justify its inclusion. Including cultural content, however interesting and useful to dictionary users, probably means having less lexical content in all but the largest dictionaries. There is certainly little room in bilingual dictionaries, unless they are written on a large scale, though it is here that cultural information may be most appreciated. However, in spite of the constraints, many dictionaries do manage to include a lot of encyclopedic information. Let us look at a few to see what sort of information is given, and then at how it is presented.

Starting with a modern American dictionary, we can consider the second edition of The Random House Dictionary of the English Language (1987). This is a large desk dictionary of 2478 pages and so has considerable scope for encyclopedic information. Within the A-Z section there are names of places in the US and elsewhere. There are also entries for geographical regions, periods of history, even Chinese dynasties. Names of people range from Roman emperors to modern comedians. There are entries for musical compositions, plays, fictional characters, constellations, common plants and birds, etc., etc., and an atlas section - information about the world, not just about the US, though data about the US figure most prominently. There are lists of Chief Justices and Presidents, US States, and US National Parks. Appendices include a directory of colleges and universities in the US and Canada, the Declaration of Independence, and the Constitution of the US. In sum, there is a great deal of general knowledge, specially geared to people in the US, but there is little about daily life, people's attitudes, or patterns of behaviour, except what can be gleaned from the lexis itself.

Turning to British dictionaries, we can look at the fourth edition of the Collins Concise Dictionary (1999). The blurb on the back cover says it includes "more people", "more places", "more facts" in its 1740 pages. It includes people who are household names in all fields, past and present, and facts about countries, cities, and towns all over the world, though it is definitely a British-based dictionary. It describes itself as "an especially handy reference book for the home, college, or office, whether you are studying, writing, or just keeping up with the news". Though there is information on mythology, medals, plants, and animals, most of the entries deal with world-famous people and places. There is no information about daily life or "little c" culture.

The desire to concentrate on general knowledge and achievement culture is not unique to English dictionaries. In France, Larousse is a well-known publisher of both dictionaries and encyclopedias. The Petit Larousse Illustré (1998, $1784 \mathrm{pp}$ ) is a monolingual French dictionary and encyclopedia combined. The first alphabetical section contains standard French vocabulary items. The second section contains encyclopedic information: names of famous people, places, buildings, and works of art from all around the world. The book is extensively illustrated with colour photographs, and is excellent as a general reference book of "western civilisation", certainly not an account of French life and culture. 
Dictionaries for learners of a language are probably the place where information about the culture of the people whose language they are learning is most needed. Unfortunately, in learner's dictionaries, such as the Oxford Advanced Learner's Dictionary (OALD), there is also the greatest need for information on grammar and synonymy, and for example sentences. Cultural information in such dictionaries is not a priority, but it is increasingly recognised that learners do need cultural information to aid their understanding of written and spoken English. A few years ago, an "encyclopedic" version of the $O A L D$ was produced. As well as the full dictionary text, this book contained information about countries of the world, famous people and places, famous events and battles, etc., though nothing about the lives of ordinary people. Longman also produced an encyclopedic version of the Longman Dictionary of Contemporary English (LDOCE) containing similar information.

In the mid 1990s, when new editions of these books were being planned, Longman retained the combined format and updated the encyclopedic information. At Oxford, we decided to do something different. Research amongst students and teachers of English as a second or foreign language showed that learners wanted to know more about the humbler aspects of British and American culture, effectively the "little c" culture. They could find out about world events and "civilisation" from reference books in their own languages. We developed a list of single items and topic areas, and decided to publish the information as a companion volume to the OALD. The Oxford Guide to British and American Culture, as it is called, contains information about all aspects of British and American culture, and is written in a restricted vocabulary suitable for learners.

In Britain the Guide is also bought by native English-speakers, especially those with children, since it is a concise reference book containing information on British and American history, politics, the arts, legends, customs, people, places, and institutions, all in an A-Z format. But the Guide also describes how British and American people live, the sports they play, the products they buy, the food they eat, and events that have shaped their lives. Many newspaper and magazine articles allude to people and events that are part of the national consciousness. The Guide provides factual information, but also indicates the connotations which some words have for a native speaker. For a full understanding of a passage, readers need to know, for instance, what names such as Richard Branson, Burberry, and Bloomingdale's signify, just as much as they need to know the meaning of expedition or balloon. But the Guide is more than a list of proper names. It contains extended definitions of words like panhandle and pier, and notes and articles on topics ranging from folk dancing to cricket, from class to soap operas, from manners to birthdays. Articles such as these present information on daily life, common attitudes, and behaviour. This book is published in a separate volume from the associated dictionary, but the information it contains could just as easily form a second section of a lexical dictionary, as in the case of the Larousse dictionary mentioned earlier. 
But let us look now closer to home, in South Africa. Let us consider first the Woordeboek van die Afrikaanse Taal, specifically volume X (1996), which covers the letter M. Most of the cultural information in this dictionary is to be found in the citations. There are few cultural as opposed to lexical entries, and many of these are Biblical, e.g. mure van Jerigo (walls of Jericho) and Man van Smarte ("man of grief", i.e. Christ). I also found Matie (a student at Stellenbosch), and Matieland, and makweta, a young black man undergoing the time of initiation in isolation. There are also names of several well-known organisations.

In the case of the Dictionary of South African English on Historical Principles (1996), where only South African English, not the entire English language, has to be covered, there is scope for a broader inclusion policy and more detailed treatment of cultural items. Once again, much of the cultural information is to be gleaned from the citations. However, there are entries for many South African institutions, historical and modern, customs, peoples, places, and regions, as well as local plants and animals.

Although not setting out to provide cultural information per se, both these dictionaries, because they describe language used mainly in South Africa and draw on its literature for their citations, carry an enormous amount of information about people and their lives. But you do need to grub and fossick around for it.

The Greater Dictionary of Xhosa (1989) contains more overtly cultural information throughout the alphabetical section. This is a descriptive and a translating dictionary, covering Xhosa, English, and Afrikaans. It also has a number of addenda containing both grammatical information and descriptions of a wide variety of Xhosa customs and traditions. The foreword to the first volume published, written by John Lamprecht, the then Vice-Chancellor of the University of Fort Hare, sums it up: "The compilers of this Dictionary have succeeded in capturing much of the living breath and feel of the Xhosa world. Here is no mere cold analysis, but a work that breathes the life of the Xhosa peoples themselves."

So far, we have looked at printed works. The world of CD-ROMS and online dictionaries may seem to hold out the possibility of including as much lexical and cultural information as we might desire. Not so. CD-ROMS are expensive to develop. The writing process takes just as long, and since they are a very visual medium, users expect more illustrations. Rights to these are often costly. In many cases the development costs would suggest a purchase price too high for potential users. Online dictionaries are plentiful, and, if you have an internet subscription, free to access. Some are linked to encyclopedias, but producers of these try to recoup costs by restricting access to some of the information to subscribers only. The most famous online products are Encarta, a Microsoft production, and Britannica.com, the online version of the Encyclopaedia Britannica. 


\section{The presentation of cultural information}

I am going to look now at some of the most common ways of introducing cultural material in dictionaries.

In encyclopedic dictionaries, especially, a whole entry may deal with a cultural item. In the Random House Dictionary of the English Language there are entries for Mozart, Fort Sumter, the bombardment of which started the American Civil War, the Nile river, and Nobel Prize, amongst many thousands of others. The Collins Concise Dictionary is similar. Many general-purpose dictionaries also include entries for culturally-based items, such as Birthday Honours, Phi Beta Kappa, and Rastafarian.

It is possible to include brief cultural points within the definition of a lexical item. An extra phrase or sentence may be sufficient. I mentioned encyclopedic definitions for salt and sugar earlier. In the Concise Oxford Dictionary, salt is defined as: "sodium chloride, a white crystalline substance which gives seawater its characteristic taste and is used for seasoning or preserving food". This does not take up much extra space but makes for a more informative definition. In the Collins Concise Dictionary the entry for eucalyptus indicates that the trees are "widely cultivated for timber and gum, as ornament, and for the medicinal oil in their leaves".

In the Greater Dictionary of Xhosa definitions are extended to include cultural information where appropriate. For example, there is cultural information at intozánè, where the English version of the text reads:

a forest tree, Englerodaphne sp, the bast of which is used for making thread for weaving sleeping-mats.

Again, more extensively, at úkùsindlékà, where the English version reads:

trad: prepare a feast for an unexpected member of the family, a relative or visitor; a beast is slaughtered and beer brewed or only beer is prepared; now also: prepare a feast quickly for an unexpected visitor by buying meat and liquor, or serve beer prepared in the traditional manner; friends and neighbours are invited to the occasion.

The material presented at the entry îxhwêlè is even more comprehensive:

herbalist who uses roots, leaves and bark of a large variety of medicinal plants in the form of infusions, decoctions, pastes, powders or steam; certain parts of animals (mammals and reptiles) are also used; the medicines are drunk, usually as purgatives, applied externally as washes or plasters, used for gargling, or as enemas, or rubbed into incisions in the skin; besides treating people, herbalists also treat kraals, homes, livestock and crops to protect them from evil influences and to make them 
prosper; the knowledge of these medicines may be obtained from a relative, eg a father, or directly from the ancestral spirits who reveal them in dreams; the herbalist operates in the fields of both white and black magic, ie his skill is used to cure ailments and drive away evil influences, alternatively also, when requested, to harm or kill people in a supernatural manner; whereas in the past the herbalist collected medicinal materials himself, many of them are now bought from people who trade in such things.

These definitions, or perhaps they should be called explanations, which are given in Xhosa, English and Afrikaans, are, I believe, one of the great strengths of this dictionary.

Bilingual and multilingual dictionaries need to consider the social and intellectual background of both or all the speech communities they serve. A more detailed explanation of meaning and connotation may be necessary to aid understanding of an item not known to one or more of the speech communities. In the Tshivenda-English Dictionary edited by van Warmelo cultural snippets follow the translation. At khwará, "pangolin", for instance, we find the following extra paragraph:

Khwara are said to be seen only after rains, therefore believed to fall from the skies with the rain. Their shells therefore serve to make rain, but shedding their blood (if done by the uninitiated) would make the rain stay away. Any man finding a khwara had to carry it to the chief's place alive without delay. Since it can escape no matter how well secured, such a man had no rest until rid of it.

The same dictionary gives fascinating interpretations of Venda proverbs. Again, in Cuenod's Tsonga-English Dictionary we find entries like nthìmbu:

one of betrothed girl's friends (female), who dances on the day the $n d z o-$ volo cattle for her are brought.

To purists all this may sound a little quaint and out of place in a dictionary, but where else is this kind of cultural information, information associated with individual words, going to be recorded?

In dictionaries such as the Woordeboek van die Afrikaanse Taal and the Dictionary of South African English on Historical Principles, citations reveal the development of meaning and usage over time but also, as we have seen, provide a wealth of cultural information, past and present. In a similar way, example sentences in learner's dictionaries and elsewhere, when carefully chosen, often provide a cultural context for a word as well as an illustration of usage.

An attractive way of including more detailed cultural information is to add a short note after the lexical entry. A note may fall within the column 
structure for the page, but yet allow cultural details to be presented separately from information on grammar and usage. Design features are important, so that the page does not look top heavy. In the Reader's Digest Afrikaans-Engelse Woordeboek / English-Afrikaans Dictionary, extra columns on either side of the two main columns contain shaded boxed notes. Most of the notes in this dictionary are to do with usage rather than culture, though some give cultural information. In the Oxford Guide to British and American Culture there are many short notes on topics such as adult education, capital punishment, homelessness, lobbying, nicknames, and nightlife. Since this is not a lexical dictionary the notes stand independently. The notes are preceded by the headword and begin and end with a ruled line to differentiate them from the rest of the A-Z text.

The Guide also includes a set of longer notes or articles on cultural topics, placed as close as possible to their alphabetical position. These are listed in the contents page to aid readers in finding them, and to encourage people to browse. These articles are on major topics, such as American English, Class, Education, Parliament, and Religion, and often take up a whole page or even a double-page spread. There are also lighter articles on Pubs and Pub Names. Articles are differentiated from the general text by being framed and presented in a different font. The book is intended primarily for learners of English, and key vocabulary for the subject under discussion is highlighted in bold type. Words preceded by an asterisk have their own entry in the Guide.

The Guide also has a set of colour pages in the middle of the book, on umbrella topics such as The history of the US and The British landscape. Colour pages are expensive and rarely affordable in dictionaries, but they do make the book attractive to potential purchasers. A black-and-white inset section would be a reasonable substitute and would still allow important cultural topics to be given prominence.

Some information can best be presented as a list, or as a table or chart. The American Random House Dictionary contains charts and tables within the A-Z text, some within the column width, some taking up more of the page. Topics include birthstones, Islands of the World, and United Nations Member Countries. The Oxford English Reference Dictionary puts charts and tables in a 100-page "factfinder" section, but perhaps the most common way of including these in general-purpose dictionaries is to put them in appendices or addenda. Common topics for appendices include lists of signs and symbols, lists of countries and their capital cities and currencies, and advice on punctuation and how to set out a letter or curriculum vitae. The Greater Dictionary of Xhosa contains a series of addenda containing information on grammar, e.g. noun classes and object concords, but most addenda in this book are numbered paragraphs describing various aspects of the Xhosa cultural heritage. Subjects include Tikoloshe (water sprite), Mamlambo (snake), Ntsikana (a famous person), Ukuhlolela, (searching for a husband), the brewing of beer, and being summoned by the river. 
Illustrations are an important means of presenting cultural information, though dictionary editors need to be aware of the high costs involved and that they, rather than the publishers, may be expected to pay for illustrations. Photographs, especially, enhance a book, but reproduction rights are expensive and good quality paper, also expensive, is necessary. Line drawings are a cheaper alternative to photographs, though research shows that these are easily misunderstood by users unfamiliar with certain techniques and conventions, such as cross-sections. Look at the illustration of $d a m^{1}$, for instance, from the Random House Dictionary:

Unless you already know what a dam in the US is like, and how it works, you might find the illustration difficult to interpret. Most illustrations are contained within the text, immediately before or after the entry to which they refer. Alternatively, they may be given as a group in the centre of the book, though this is less satisfactory as they are remote from the entry they illustrate.

Maps are frequently added to dictionaries, often in bilingual dictionaries to show names of countries in the target language. In larger dictionaries there may be a series covering the whole world. In other dictionaries maps may cover only the particular region or country where the dictionary is to be marketed and are more detailed. Some maps are in colour, but a black-and-white drawing is often just as useful.

Endpapers may also be used to present cultural information, if they are not needed for lists of abbreviations or symbols. Topics presented on endpapers may include flags, timelines, or lists of presidents. Timelines can give a graphic summary presentation of local political and social history which would not be appropriate in an A-Z section. Maps may also be presented on endpapers. 


\section{Implications for South African lexicographers}

We can now draw a few threads together and think of the cultural and lexicographic situation in South Africa.

South Africa is multilingual and multicultural. Although there are some shared aspects of culture, such as political institutions, the justice system, sports, and music, many traditions, practices, events, and heroes are little known outside individual cultural groups. For the Xhosa people, at least, the Xhosa Dictionary Unit is recording a fair amount of cultural information, which is accessible not only to Xhosa speakers but also to English and Afrikaans speakers. Though the dictionary may be targeted primarily at the Xhosa community, its trilingual format means it is more widely accessible. This is something that needs to be seriously considered.

It is impossible to talk about language and culture now without mentioning the African Renaissance. The African Renaissance promotes African culture. It is trying to encourage renewed awareness of Africa and things African, national and local, amongst outsiders, and to engender feelings of honour and pride in their various cultures among Africans. It reconfirms respect for older societies and customs but also encourages ongoing creativity. Laurence Wright (2000, in press) quotes Paul Ricoeur (1965: 283): "Only a living culture, at once faithful to its origins and ready for creativity on the levels of art, literature, philosophy and spirituality, is capable of sustaining the encounter [with] other cultures ..." We need to develop cultures, not just preserve them, and to make them known to a wider audience. Culture is not something that will survive without being nurtured or "cultivated", and the responsibility for this needs to be shared.

Writing cultural dictionaries or reference works in the South African context sounds like an ambitious undertaking. But perhaps it is something we need to consider. I mean specifically books that are useful for schools, students of culture, and for members of other cultural groups, "dictionaries of culture" on the lines of the Guide to British and American Culture. If this seems beyond our remit or too ambitious for the moment then perhaps, as lexicographers, we can consider including more cultural information in dictionaries. As we have seen, language and culture are closely related, and all sorts of cultural information can be pinned to a word or name. Who else is in a position to gather together all the threads? Dictionaries containing encyclopedic information, provided they are of a manageable size, often appear more user-friendly, more interesting, and browsable to the general public. They are seen as general reference books and good value for money.

"Dictionary" is a powerful word, and it lends authority to the information contained in any book with "dictionary" in the title. Many lists of subject terms, on topics ranging from psychology to geology, are called "dictionaries". Dictionaries of terminology, learner's dictionaries, and cultural dictionaries, can all

be classified as "dictionaries for special purposes". Perhaps there is scope for 
future collaboration between dictionary units on a range of cultural dictionaries. Culture can be divisive, insular, and threatening, especially if it appears closed to others. More widely available information may lead to greater interest, greater acceptance.

Transformation of the curriculum in South Africa is still in progress, and we do not yet know what exactly will be included in Curriculum 21. But it will be outcomes-based, and will probably incorporate many features of Curriculum 2005. The latter recognised "Arts and Culture" as a learning area and targeted the following "specific outcomes":

1. demonstrating an understanding of the origins, functions and dynamic nature of culture,

2. demonstrating an ability to access creative art and cultural processes to develop self-esteem and promote healing, and

3. acknowledging, understanding, and promoting historically marginalised arts and cultural forms and practices.

Another highly relevant learning area is, or was, "Language, Literacy and Communication". Specific outcomes here include:

1. showing critical awareness of language use, and

2. responding to aesthetic, affective, cultural and social values in texts.

Culture, especially "little c" culture, is also very much involved in the "Life Orientation" learning area. Students should learn to:

1. respect the rights of people to hold personal beliefs and values, and

2. demonstrate value and respect for human rights as reflected in ubuntu and other similar philosophies.

Culture, particularly behavioural culture, is right at the heart of the humanities curriculum, closely linked to language and literacy and also to social studies.

It may be difficult to "teach" culture, but it is possible to help people to become more culturally aware, aware of their own cultural behaviour and aware that other people's cultural practices, though they may be different, are equally valid. Awareness involves having information, information about society and social practices, history, traditions, and values, and I hope we can be amongst those instrumental in supplying it. With this in mind, I would like us to look afresh at the level and type of cultural content of our dictionaries, and to consider whether it meets the needs of prospective users. 


\section{References}

Becher, Gabriele. 1995. Culture and Institutions in Translator Training. Teaching Culture-specific Concepts to Prospective Translators: A Case Study. Thelen, M. and B. LewandowskaTomaszczyk (Eds.). 1995. Translation and Meaning, Part 3: 293-304. Maastricht: Universitaire Pers.

Béjoint, Henri. 1994. Tradition and Innovation in Modern English Dictionaries. Oxford: Clarendon Press.

Chaffey, William. 1992. Culture-specific Elements in Translation. Lewandowska-Tomaszczyk, B. and M. Thelen (Eds.). Translation and Meaning, Part 2: 147-153. Maastricht: Universitaire Pers.

Crystal, David. 19972. The Cambridge Encyclopedia of Language. Cambridge: Cambridge University Press.

Goodenough, W.H. 1957. Cultural Anthropology and Linguistics. Garvin, P.L. (Ed.). Report of the Seventh Round Table Meeting on Linguistics and Language Study. Washington, DC: Georgetown University Press.

Gouws, Rufus H. 1996. Bilingual Dictionaries and Communicative Equivalence for a Multilingual Society. Lexikos 6: 14-31.

Gumperz, J.J. 1970. Sociolinguistics and Communication in Small Groups. Pride, J.B. and Janet Holmes (Eds.). 1972. Sociolinguistics: Selected Readings. Harmondsworth: Penguin.

Kaschula, Russell H. and Christine Anthonissen. 1995. Communicating across Cultures in South Africa: Towards a Critical Language Awareness. Johannesburg: Hodder \& Stoughton/Witwatersrand University Press.

Kotzé, Ernst. 1999. Translating Culture in Bilingual Dictionaries. Lexikos 9: 89-107.

Mengham, Rod. 1993. The Descent of Language: Writing in Praise of Babel. London: Bloomsbury.

Pinnock, Patricia Schonstein. 1994. Xhosa: A Cultural Grammar for Beginners. Cape Town: African Sun Press.

Ricoeur, Paul. 1965. Universal Civilization and National Cultures. History and Truth: 271-284. (Trans. Charles A. Kelbley). Evanston: Northwestern University Press.

Urdang, Laurence. 2000. Review of Hartmann, R.K.K. and G. James: Dictionary of Lexicography. International Journal of Lexicography 13(1): 35-42.

Wardhaugh, Ronald. 1986. An Introduction to Sociolinguistics. Oxford: Basil Blackwell.

Wright, Laurence. 2000, in press. Culture and Civilisation in South Africa: Some Questions about the "African Renaissance". English Academy Review 16.

\section{Dictionaries and Encyclopedias}

Britannica.com. 1999-2000. Chicago: Britannica.com Inc.

Collins Concise Dictionary. 19994. Glasgow: Collins.

Crowther, Jonathan and Kathryn Kavanagh (Eds.). 19955. Oxford Advanced Learner's Dictionary of Current English. Oxford: Oxford University Press.

Crowther, Jonathan and Kathryn Kavanagh (Eds.). 1999. Oxford Guide to British and American Culture for Learners of English. Oxford: Oxford University Press.

Cuenod, R. 1967. Tsonga-English Dictionary. Johannesburg: Sasavona. 
A Dictionary of South African English on Historical Principles. 1996. Oxford: Oxford University Press, in association with the Dictionary Unit for South African English.

Encarta Encyclopedia and World English Dictionary. 1997-2000. Redmond: Microsoft Corporation.

Encyclopaedia Britannica. 1971. Chicago: Encyclopaedia Britannica/William Benton.

Gove, Philip Babcock (Ed.). 1961. Webster's Third New International Dictionary of the English Language. London: G. Bell \& Sons; Springfield: G \& C Merriam.

Johnson, Samuel 1755. A Dictionary of the English Language. London: J. and P. Knapton et al. (facsimile edition, 1979. London: Times Books).

Longman Dictionary of Contemporary English. 19953. Harlow: Longman.

Murray, James A.H. et al. Oxford English Dictionary. 1933. Oxford: Oxford University Press.

The Oxford English Reference Dictionary. 1996. Oxford: Oxford University Press.

Pahl, H.W. et al. 1989. The Greater Dictionary of Xhosa, Volume 3, Q to Z. Alice: University of Fort Hare.

Pearsall, Judy (Ed.). Concise Oxford Dictionary. 199910. Oxford: Oxford University Press.

Le Petit Larousse Illustré. 1998. Paris: Larousse.

The Random House Dictionary of the English Language. 19872. New York: Random House.

Reader's Digest: Afrikaans-Engelse Woordeboek / English-Afrikaans Dictionary. 1987. Cape Town: Reader's Digest Association.

Van Warmelo, N.J. 1989. Venda Dictionary: Tshivenda-English. Pretoria: J.L. van Schaik.

Webster, Noah 1783. The American Spelling Book. Boston.

Webster, Noah 1806. A Compendious Dictionary of the English Language. Boston.

Webster, Noah 1828. An American Dictionary of the English Language. New York: S. Converse (facsimile edition, 1980. San Francisco: Foundation for American Christian Education).

Webster's New International Dictionary. 1909. London: G. Bell \& Sons / Springfield: G \& C Merriam.

Woordeboek van die Afrikaanse Taal. 1950- . Pretoria: Government Printer / Stellenbosch: Bureau of the WAT. 